\title{
Prevalence of hepatitis B and C viral co-infections among HIV-1 infected individuals in Nairobi, Kenya
}

\author{
Beatrice Mukami Muriuki', Michael Muita Gicheru', Dorcas Wachira ${ }^{3}$, Anthony Kebira Nyamache ${ }^{2,3^{*}}$ \\ and Samoel Ashimosi Khamadi ${ }^{3}$
}

\begin{abstract}
Background: Hepatitis B virus (HBV) and Hepatitis C virus (HCV) co-infections among HIV-1 infected individuals are growing worldwide health problems characterized by lack of effective vaccines, need for expensive treatment, chronicity of morbidity and associated mortality. Their prevalence and distribution patterns continue to vary across geographical locations with high prevalence being detected among high risk populations. To determine the prevalence of HBV and HCV among HIV-1 infected individuals, blood samples were collected from consenting study subjects visiting comprehensive HIV clinics in Nairobi during the period between October and December 2009.
\end{abstract}

Methods: Blood samples from volunteers were screened with ELISA tests for detecting HIV, HBV surface antigen (HBsAg) and anti-HCV antibodies.

Results: In a total of three (300) hundred infected individuals consisting of $129(43 \%)$ males and 171 (57\%) females 15.3\% (46/300) were HIV-1 co-infected with either HBV or HCV or both, 10.3\% (31/300) with HIV-1 and HCV and 6\% (18/300) with HIV-1 and HBV infections. However, only three individuals (1\%) were coinfected with the three viruses (HIV/HBV/HCV).

Conclusion: Though, low levels of co-infection with all three viruses were reported, there could be higher prevalence rates than reported here especially among high risk populations.

Keywords: Hepatitis, HIV-1, ELISA

\section{Background}

Human immunodeficiency Virus (HIV), Hepatitis B virus (HBV), and Hepatitis $\mathrm{C}$ virus (HCV), are the three most common chronic viral infections all over the world. They share similar transmission routes including sexual, bloodblood contact, and injecting drug usage [1,2]. Co-infection with $\mathrm{HIV}$ and $\mathrm{HCV}$ and/or $\mathrm{HBV}$ is very common in certain populations, such as intravenous drug users (IDUs) who often share the contaminated needles/syringes for intravenous drug injection. It has been reported that the world prevalence of HIV-HCV co-infection among IDUs can surpass $90 \%$ in certain populations [3,4]. Besides,

\footnotetext{
* Correspondence: akibera2000@gmail.com

${ }^{2}$ Department of Plant and Microbial sciences, Kenyatta University, Nairobi, Kenya

${ }^{3}$ Kenya Medical Research Institute, Centre for Virus Research, Nairobi, Kenya
} Full list of author information is available at the end of the article the rates of HIV-HBV co-infection are reported as high as $10-20 \%$ in countries where HBV infection is either endemic or intermediate to high HBV cases [5]. It has been observed that HBV/HIV co infection leads to increased morbidity and mortality as compared to HIV or HBV mono-infections [5]. The ever increasing burden of these infections has become a growing concern [6]. With increased access to antiretroviral drugs for HIV patients, migrating populations and social networking by intravenous drug use, cases of HBV and HCV co infections have been on the rise [7], coupled with the dramatic rise in survival rates of these individuals [8]. As a result of these factors, cases of hepatic diseases have also been on the rise [9]. Studies show that HIV co infection adversely impacts on the natural history of $\mathrm{HBV}$ and HCV [7] by accelerating progression to chronic live disease due to drug-related hepatotoxicity 
Table 1 Characteristics of HIV positive, HIV/HCV and HIV/HBV co-infected individuals

\begin{tabular}{|c|c|c|c|c|c|c|c|c|}
\hline Categories & All $n=(300)$ & Male & Female & HIV-1 only & HIV-1/HBV & HIV-1/HCV & HIV-1/HBV/HCV & $\mathrm{p}=$ value \\
\hline Age(yrs)[mean (S.D)] & $33.9(9.1)$ & $35.7(8.7)$ & $32.6(9)$ & $34.24(9.138)$ & $34.8(6.5)$ & $30.6(8.3)$ & $33.3(7.2)$ & 0.001 \\
\hline $\begin{array}{l}\text { CD4+ T cell count } \\
\text { (Cells/mm3) (Mean) }\end{array}$ & $388( \pm 262.95)$ & $375( \pm 250.2)$ & $398( \pm 226.9)$ & $400.7( \pm 270.1)$ & 252.2 & $325.8( \pm 228.7)$ & $576.7( \pm 213.5)$ & 0.02 \\
\hline HBV (\%) & & 10/18 (55\%) & $8 / 18(45 \%)$ & & & & & \\
\hline HCV (\%) & & $14 / 30(46.7 \%)$ & 16/30 (53.3\%) & & & & & \\
\hline Patients [n] (\%) & $300(100)$ & $129(43.0)$ & $171(57)$ & $248(82.7)$ & $18(6)$ & $30(10 \%)$ & $3(1)$ & \\
\hline
\end{tabular}

and hepatitis reactivation [10-12]. At this stage, most patients are likely to die due to liver-related diseases compared to those without HIV infection [13].

In Kenya, the HIV-1 epidemic has been well documented. However, little data exists on $\mathrm{HBV}$ and $\mathrm{HCV}$ co infection among HIV-1 positive patients [14]. This study was carried out among HIV positive patients who were accessing CD4 testing services, to determine the levels of HBV and HCV co infections. This was done with the knowledge that such patients are at a high risk of a rapid disease progression coupled with development of liver cirrhosis and hepatocellular carcinoma [15].

\section{Methods}

Between October and December 2009, a cross sectional study was carried out involving three (300) hundred consenting HIV-1 infected patients. The volunteers were recruited after providing written consent i.e. for persons aged above 18 years and assent from guardians and mothers of persons aged below 18 years. The enrolled volunteers were aged between 4-59 years of age. The participants were recruited through stratified sampling from nine Nairobi-based health centres namely; Baraka, Ngong, Pumwani, Ongata Rongai, Kangemi, Huruma, Kamiti, Ngaira and Waithaka. Blood was collected aseptically into $10 \mathrm{ml}$ vacutainer tubes (Becton Dickson, New Jersey USA) for biochemical, CD4+ count and viral serology tests. The CD4+ $\mathrm{T}$ lymphocytes assay was performed within three hours of collection, while serum for serological assays for hepatitis $\mathrm{C}$ and $\mathrm{B}$ markers was stored at $-20^{\circ} \mathrm{C}$ until the time for assay [16]. CD4+T lymphocytes count was determined by flow cytometry using Becton Dickson Facs calibur machine [17]. The determination of anti hepatitis $C$ virus IgG antibody (anti HCV) and Hepatitis B antigen (HBsAg) were conducted by use of antibody capture ELISA, enzymelinked immunosorbent assay kit (Hepanostika HBsAg) (Murex Biotech Ltd, Dartford, UK) [18] and Murex anti$\mathrm{HCV}$ kit for Hepatitis $\mathrm{C}$ virus, (Murex anti-HCV version 4.0) [19]. HIV-1 and HIV-2 Vironostika HIV Uni-Form II Ag/Ab (Bio-Merieux, Boxtel, The Netherlands) following the manufacturer's instructions.

\section{Ethical considerations}

This study was ethically approved by Kenya Medical Research Institute (KEMRI) National Scientific Steering Committee SCC reference no. 1394 before it was executed.

\section{Data analysis}

All generated data was entered into a database, cleaned and analyzed using SPSS version 11.5. The sero-prevalence for $\mathrm{HBV}$ and $\mathrm{HCV}$ were expressed as a percentage for the entire study group. Pearsons Chi square was used to test the association between level of immunosuppression and $\mathrm{HBV} / \mathrm{HCV}$ infection. Simple linear correlation analysis was used to determine the association between age and $\mathrm{HBV} / \mathrm{HCV}$ infection.

\section{Results}

Three (300) hundred HIV patients comprising 129 (43\%) males and 171 (57\%) females were enrolled in this study. Their age ranged between 4-59 years with a mean age of $33.92( \pm 8.96)$ years with men $36.0( \pm 8.7)$ and $32.6( \pm 8.97)$ years for females (Table 1$)$. There were 48 (16\%) co-infections with 18 (56\%) HIV/HBV, 30 (10.\%) HIV/HCV, with $3(1 \%)$ of those infected

Table 2 Prevalence of HIV-1, HBV, HCV coinfections by age and CD4+ counts

\begin{tabular}{ccccccc}
\hline $\begin{array}{c}\text { Age } \\
\text { group }\end{array}$ & (n/300) & HIV & HBV/HCV & HBV & HCV & $\begin{array}{c}\text { Average CD4 } \\
\text { count }\end{array}$ \\
\hline $1-5$ & 2 & 2 & - & - & - & 1211 \\
$6-10$ & 2 & 1 & - & - & 1 & 370 \\
$11-15$ & 2 & 2 & - & - & - & 537 \\
$16-20$ & 4 & 3 & - & - & 1 & 409 \\
$21-25$ & 40 & 31 & 1 & 2 & 6 & 461 \\
$26-30$ & 73 & 61 & - & 4 & $8(11.1)$ & 401 \\
$31-35$ & 61 & 52 & - & 3 & 6 & 350 \\
$36-40$ & 48 & 35 & 2 & 5 & $6(12.8)$ & 356 \\
$41-45$ & 40 & 34 & - & 4 & 2 & 380 \\
$46-50$ & 18 & 17 & - & - & 1 & 272 \\
$51-55$ & 10 & 10 & - & - & - & 432 \\
$56-60$ & 3 & 3 & - & - & - & 352 \\
Total & $\mathbf{3 0 0}$ & $\mathbf{2 4 8}$ & $\mathbf{3}$ & $\mathbf{1 8}$ & $\mathbf{3 1}$ & \\
\hline
\end{tabular}


being detected with $\mathrm{HIV} / \mathrm{HBV} / \mathrm{HCV}$ coinfections. However, 248 (82.7\%) were HIV monoinfected (see Table 1). In relation to gender, there was no difference in gender in dual infections of either HBV/HIV or HCV/HIV. However, males had the highest prevalence rates of $\mathrm{HBV}$ infection (55\%) with females leading in $\mathrm{HCV}$ infections (53.3\%). Among those infected, majority of them were aged 25 and 40 years (see Table 2). In addition, the mean CD4 counts in HBV/HIV coinfected patients were low compared to those either $\mathrm{HCV} / \mathrm{HIV}$ co-infected patients or among HIV monoinfections (see Table 1).

Table 3 Surveys of hepatitis B virus surface antigen (HBsAg) and hepatitis C antibody (HCV Ab) prevalence in HIV-infected persons conducted in Kenya and neighboring sub-Saharan Africa countries, 1996-2013

\begin{tabular}{|c|c|c|c|c|c|c|c|}
\hline \multirow[b]{2}{*}{ Author } & \multirow[b]{2}{*}{ Publication year } & \multirow[b]{2}{*}{ Country } & \multirow[b]{2}{*}{ Population } & \multirow[b]{2}{*}{ Sample size } & \multicolumn{3}{|c|}{ Prevalence rates } \\
\hline & & & & & HBsAg (\%) & HCV (\%) & HCV/HBV/HIV (\%) \\
\hline Muriuki et al. (current study) & 2013 & Kenya & Outpatient & 300 & 6 & 10.3 & \\
\hline Mutuma et al. [34] & 2011 & Kenya & Outpatient & 51 & 8.8 & & \\
\hline Kapembwa et al. [19] & 2011 & Zambia & Inpatient & 323 & 9.9 & 2.2 & \\
\hline Moore et al. [26] & 2010 & Malawi & Inpatient & 300 & 6.7 & 5.7 & \\
\hline Di Bisceglie et al. [35] & 2010 & South Africa & Outpatient & 502 & 4.8 & & \\
\hline Mboto et al. [25] & 2010 & The Gambia & Outpatient & 1500 & & 0.6 & \\
\hline Kerubo et al. [23] & 2010 & Kenya & outpatients & & & 0.7 & 0.3 \\
\hline Belay et al. [36] & 2010 & Ethiopia & Blood donors & 6321 & 4.7 & 0.7 & \\
\hline Lukhwareni et al. [37] & 2009 & South Africa & Outpatient & 192 & 22.9 & & \\
\hline Oshitani et al. [38] & 1996 & Zambia & Outpatient & 340 & 7.1 & & \\
\hline Harania et al. [22] & 2008 & Kenya & Outpatient & 378 & 6.1 & 1.1 & \\
\hline Nyirenda et al. [27] & 2008 & Malawi & Inpatient & 226 & 17.5 & 4.5 & \\
\hline Otegbayo et al. [28] & 2008 & Nigeria & Outpatient & 1779 & 11.9 & 4.8 & \\
\hline Diop-Niaye et al. [30] & 2008 & Senegal & Outpatient & 363 & 16.8 & 1.6 & \\
\hline Shimeli et al. [39] & 2008 & Ethiopia & Outpatient & 305 & 3.9 & & \\
\hline Fimhaber et al. [35] & 2008 & South Africa & Outpatient & 502 & 4.8 & & \\
\hline Hoffmann et al. [40] & 2008 & South Africa & Outpatient & 537 & 19.7 & & \\
\hline Nagu et al. [20] & 2008 & Tanzania & Outpatient & 260 & 17.3 & 18.1 & \\
\hline Pirillo et al. [29] & 2007 & Uganda & Antenatal & 164 & 4.9 & 0.6 & \\
\hline Telatela et al. [32] & 2007 & Tanzania & Outpatient & & 15 & 13.8 & \\
\hline Lesi et al. [41] & 2007 & Nigeria & outpatients & 240 & 9.2 & 5.8 & 1.5 \\
\hline Pirillo et al. [29] & 2007 & Rwanda & antenatal & 82 & 2.4 & 4.9 & \\
\hline Wester et al. [42] & 2006 & Botswana & Outpatient & 160 & 10.6 & & \\
\hline Okoth et al. [43] & 2006 & Kenya & Outpatient & & 15 & & \\
\hline Otedo et al. [44] & 2004 & Kenya & Outpatient & 599 & 47 & & 53 \\
\hline Ejele et al. [45] & 2004 & Nigeria & outpatient & 342 & 9.7 & & 1 \\
\hline Rouet et al. [24] & 2004 & Cote d'Ivoire & Antenatal & 501 & 9 & 1.2 & \\
\hline Mustapha et al. [46] & 2004 & Gombe Nigeria & outpatients & 200 & 26.5 & & \\
\hline Kallestrup et al. [31] & 2003 & Zimbabwe & Outpatient & 124 & & 0.8 & \\
\hline Kasolo et al. [47] & 2003 & Zambia & Antenatal & 214 & 31.3 & & \\
\hline Ampofo et al. [42] & 2002 & Nigeria & blood donors & & 15 & 8.4 & \\
\hline Sud et al. [48] & 2001 & Nigeria & outpatients & 80 & 22.2 & & \\
\hline Lodenyo et al. [44] & 2000 & South Africa & Outpatient & 100 & 6 & 1 & \\
\hline Rahlenbeck et al. [49] & 1997 & Ethiopia & outpatients & 2186 & 14.4 & & \\
\hline Oshitani et al. [38] & 1996 & Zambia & Outpatient & 340 & 7.1 & & \\
\hline Fainboim et al. [33] & 1999 & Argentina & outpatients & 484 & 14.5 & 58.5 & \\
\hline
\end{tabular}




\section{Discussion}

With the increased access to antiretroviral therapy in resource limited settings, people living with HIV/AIDS will continue to live longer. However, morbidity and mortality due to co-infections with other viruses will increasingly become important. Although co infections with HBV and $\mathrm{HCV}$ among HIV positive patients is well documented in developing countries, the demographics and impact of these infections are not well defined in low resource countries like Kenya. The need for new data on hepatitis coinfections to guide health policy is on management of HIV coinfected a patient is paramount [19].

In this study, we examined the prevalence of $\mathrm{HBV}$ and HCV among HIV infected patients seeking CD4 testing services. From the results, it is clear that the co infection rates of HIV-infected patients with HBV and $\mathrm{HCV}$ was high $(>6 \%)$. This number is high even though the study participants were persons who were seeking CD4 testing services i.e. probably immunosuppressed and not representative of the general population. This has an indication that hepatitis infection in HIV-infected persons may be higher than that of the general population. Co -infection with $\mathrm{HCV}$ was also high (10\%). This was higher than what we could expect in the general population i.e. about 5\% $[20,21]$. Compared to previous studies in Kenya on similar populations, these findings were contrarily higher $1.1 \%$ [22]; 0.7\% [23], including those from Zambia (2.2\%) [19], Cote d'voire (1.2\%) [24], Gambia (0.6\%) [25], Malawi (5.7\%) [26,27], Nigeria (4.8\%) [28], Rwanda (4.9\%) [29], Senegal (1.6\%) [30] Uganda (0.6\%) [31] and Zimbabwe $(0.8 \%)$ [31] (Table 3). The higher rates could probably due to increased free access to antiretroviral therapy and diverse study subjects. However, the high estimate of $\mathrm{HCV}$ prevalence among HIV infected patients in this study were similar to those obtained in Tanzania; [21,32] but less to those obtained in Argentina [33].

The HIV/HBV co infection rates (6\%) detected in this study was found to be consistent with findings from other studies carried out in Kenya [22,50], Zambia [19,34], Cote d' Ivore [24], Malawi [25], Nigeria [38], Ethiopia [41] and South Africa [39]. However, these findings were low compared to those previous obtained in Kenya (55.8\%) among liver failure patients [43,44] Tanzania [32,51], Zambia [47], Botswana [42], Malawi [27], Nigeria [28,42,46,48], Ethiopia [40], Argentina [34] South Africa [37,40] (Table 3). These prevalence rates were also found to be higher than those obtained in Ethiopia [35,52], South Africa [35,53], Uganda and Rwanda [29]. The observed diverse prevalence rates across different countries were associated with the diversity of patients from different population groups, sample size, test kit sensitivity and specificity [52].

The HIV co-infection rates as per gender in this study was found not to be significantly higher among male study subjects (19.2\%) as compared to their female counterparts $(14.3 \%)(\mathrm{p}>0.061)$. This finding was comparable to reports from elsewhere [22]. This observation may have been accounted for by the fact that men are more likely to have multiple sex partners and also practice unprotected sex due to the polygamous nature of their relationships.

We also observed a significant high prevalence in $\mathrm{HCV}$ antibody among HIV infected patients. The probable reason could be due to the shared modes of transmission of both viruses in the study patients. The prevalence of HIV/ $\mathrm{HCV}$ was also found to be higher in Males (11.6\%) as compared to females (9.4\%). However, the difference was not significant $(\mathrm{p}>0.055)$. This observation was similar to previous studies conducted in Kenya [23], Nigeria [4,21] and contrarily to other findings of older females being more co- infected [23,51].

Three patients (1\%) were found co-infected with trio $\mathrm{HIV}, \mathrm{HBV}$ and $\mathrm{HCV}$ infections in this study. These findings were similar to those obtained previously in Kenya [23,25], Nigeria [53] and Ethiopia [29] indicating a maintained low rates of these trio infections $[22,23,25,35,36]$ (Table 3).

\section{Conclusions}

In spite of carrying out the study only among HIVinfected patients, it was evident that co-infection rates with HIV and $\mathrm{HCV}$ and/or HBV are higher among HIV infected individuals than populations that are HIV negative. There is therefore a need for constant surveillance of these infections that pose a challenge in vaccine design and treatment options.

\section{Abbreviations}

HBV: Hepatitis B virus; HCV: Hepatitis C virus; HBsAg: Hepatitis B surface antigen; Anti-HCV: Anti-HCV antibody; ELISA: Enzyme-linked immunosorbent assay.

\section{Competing interests}

The authors declare that they have no competing interests.

\section{Authors' contributions}

BMM participated in data collection and carried out the analysis together with AKN, NW, NMG and SAK. They all participated in compiling the manuscript. ANK helped in preparing Tables. SAK and AKN assisted with the overall study design and supervised the statistical analysis. NMG and AKN were responsible for the overall supervision of the study and together with SAK supervised laboratory work. All authors read and approved the final manuscript.

\section{Acknowledgements}

Authors wish to appreciate and acknowledge the patients who participated in this study.

\section{Author details}

${ }^{1}$ Department of Zoological Sciences, Kenyatta University, Nairobi, Kenya. ${ }^{2}$ Department of Plant and Microbial sciences, Kenyatta University, Nairobi, Kenya. ${ }^{3}$ Kenya Medical Research Institute, Centre for Virus Research, Nairobi, Kenya.

Received: 11 February 2013 Accepted: 3 September 2013 Published: 9 September 2013 


\section{References}

1. Saravanan S, Velu V, Kumarasamy N, Nandakumar S, Murugavel K, et al: Coinfection of hepatitis $B$ and hepatitis $C$ virus in HIV-infected patients in south India. World J Gastroenterol 2007, 13:5015-5020.

2. Koziel M, Peters M: Viral hepatitis in HIV infection. N Engl J Med 2007, 356:1445-1454.

3. Maier I, Wu G: Hepatitis C and HIV co-infection: a review. World J Gastroenterology 2002, 8:577-579.

4. Aceijas C, Rhodes T: Global estimates of prevalence of HCV infection among injecting drug users. Int J Drug Policy 2000, 18:352-358.

5. Thio $C$ : Hepatitis $B$ and human immunodeficiency virus coinfection. Hepatology 2009, 49:138-145.

6. Nikolopoulos GK, Paraskevis D, Hatzitheodorou E, et al: Impact of hepatitis $B$ virus infection on the progression of AIDS and mortality in HIVinfected individuals: a cohort study and meta-analysis. Clin Infect Dis 2009, 48:1763-1771.

7. Lacombe K, Boyd A, Gozlan J, Lavocat F, Girard PM, Zoulim F: Drug resistance and immune escape HBV mutants in HIV-infected hosts. Antivir Ther 2010, 15:493-497.

8. Sulkowski MS, Thomas DL, Chaisson RE, et al: Hepatotoxicity associated with antiretroviral therapy in adults infected with human immunodeficiency virus and the role of hepatitis $C$ or $B$ virus infection. JAMA 2000, 283(1):74-80.

9. Sulkowski MS, Thomas DL, Mehta SH, et al: Hepatotoxicity associated with nevirapine or efavirenz-containing antiretroviral therapy: role of hepatitis C and B infections. Hepatology 2002, 35(1):182-189.

10. Benhamou Y, Bochet $M$, Thibault $V$, et al: Safety and efficacy of adefovir dipivoxil in patients coinfected with HIV-1 and lamivudine-resistant HBV: an open-label pilot study. Lancet 2001, 358:718-723.

11. Gamal S, Mousa SA: Current status and future directions in the management of chronic hepatitis C. Virol J 2012, 9:57.

12. Man-Fung $Y$, Ching-Lung L: Treatment of chronic hepatitis B: Evolution over two decades. J Gastroenterol Hepatol 2011, 26(Suppl. 1):138-143.

13. Tan $Y$, Wei $Q H$, Chen $L$, Chan PC, Lai WS, et al: Molecular Epidemiology of HCV Monoinfection and HIV/HCV Coinfection in Injection Drug Users in Liuzhou, Southern China. PLOS ONE 2008, 3(10):e3608. doi:10.1371/journal. pone.0003608

14. Muasya T, Lore W, Yano K, Yatsuhashi H, Owit FR, Fukuda M, Tamada MY, Kulundu J, Tukei J, Okoth FA: Prevalence of hepatitis $c$ virus and its genotypes among a cohort of drug users in Kenya. East Afr Med J 2008, 85:7.

15. Zhou Y-H, Liu F-L, Yao Z-H, Duo L, Li H, et al: Comparison of HIV-, HBV-, $\mathrm{HCV}$ - and Co-Infection Prevalence between Chinese and Burmese Intravenous Drug Users of the China-Myanmar Border Region. PLOS ONE 2011, 6(1):e16349. doi:10.1371/journal.pone.0016349.

16. Landay A, Ohlsson-Wilhelm B, Giorgi J: Application of flow cytometry to the study of HIV infection. AIDS 1990, 4:479-497.

17. Zaaijer $H$, Vrielink $H$, Koot M: Early detection of hepatitis B surface antigen and detection of HBsAg mutants: a comparison of five assays. Vox sang 2001, 81:219-221.

18. Gretch DR: Diagnostic tests for hepatitis C. Hepatology 1997, 26:43-47.

19. Kapembwa KC, Goldman JD, Lakhi S, Banda Y, Bowa K, Vermund SH, Mulenga J, Chama D, Chi BH: HIV, hepatitis B, and hepatitis C in Zambia. J Global Infect Dis 2011, 3:269-274.

20. Nagu T, Bakari M, Matee M: Hepatitis A, B and C viral co-infections among HIV-infected adults presenting for care and treatment at Muhimbili National Hospital in Dar es Salaam, Tanzania. BMC Publ Health 2008, 8:416.

21. Karoney MJ, Siika AM: Hepatitis C virus (HCV) infection in Africa: a review) Pan Afr Med J 2013, 14:44. doi:0.11604/pamj.2013.14.44.2199. Epub 2013 Jan 31.

22. Harania R, Karuru J, Nelson M, Stebbing J: HIV, hepatitis B and C coinfection in Kenya. AIDS 2008, 22:1221-1222.

23. Kerubo G, Khamadi SA, Mwau M, Madise N, Azeh A: Hepatitis B, hepatitis $C$, and HIV-1 coinfection in two selected informal urban settlements in Nairobi, Kenya. AIDS 2010 - XVIII International AIDS Conference. Abstract no. CDB0093.

24. Rouet F, Chaix ML, Inwoley A, Msellati P, Viho I, Combe P, et al: HBV and HCV prevalence and viraemia in HIV-positive and HIV-negative pregnant women in Abidjan, Cote d'Ivoire: The ANRS 1236 study. J Med Virol 2004 74:34-40.

25. Mboto Cl, Fielder M, Davies-Russell A, Jewell AP: Hepatitis C virus prevalence and serotypes associated with HIV in The Gambia. Br J Biomed Sci 2010, 67:140-144.
26. Moore E, Beadsworth MB, Chaponda M, Mhango B, Faragher B, Njala J, et al: Favourable one-year ART outcomes in adult Malawians with hepatitis B and C co-infection. J Infect 2010, 61:155-163.

27. Nyirenda M, Beadsworth MB, Stephany P, Hart CA, Hart IJ, Munthali C, et al: Prevalence of infection with hepatitis $B$ and $C$ virus and coinfection with HIV in medical inpatients in Malawi. J Infect 2008, 57:72-77.

28. Otegbayo JA, Taiwo BO, Akingbola TS, Odaibo GN, Adedapo KS, Penugonda $S$, et al: Prevalence of hepatitis $B$ and $C$ seropositivity in a Nigerian cohort of HIV-infected patients. Ann Hepatol 2008, 7:152-156.

29. Pirillo MF, Bassani L, Germinario EA, Mancini MG, Vyankandondera J, Okong $P$, et al: Seroprevalence of hepatitis B and C viruses among HIV-infected pregnant women in Uganda and Rwanda. J Med Virol 2007, 79:1797-1801.

30. Diop-Ndiaye H, Toure-Kane C, Etard JF, Lo G, Diaw P, Ngom-Gueye NF, et al: Hepatitis B, C seroprevalence and delta viruses in HIV-1 Senegalese patients at HAART initiation (retrospective study). J Med Virol 2008, 80:1332-1336

31. Kallestrup P, Zinyama R, Gomo E, Dickmeiss E, Platz P, Gerstoft J, et al: Low prevalence of hepatitis $C$ virus antibodies in HIV-endemic area of Zimbabwe support sexual transmission as the major route of HIV transmission in Africa. AIDS 2003, 17:1400-1402

32. Telatela S, Mecky MA, Munubhi E: Seroprevalence of hepatitis B and C viral co-infections among children infected with human immunodeficiency virus attending te paediatric HIV care and treatment center at Muhimbili National Hospital in Dar-es-Salaam, Tanzania. BMC Publ Health 2007, 7:338.

33. Fainboim H, Gonzalez J, Fassio P: Prevalence of hepatitis viruses in an anti-Human Immunodeficiency Virus positive population from Argentina- A multicentre study. J viral Hepatology 1999, 6:53-57. 28.

34. Oshitani H, Kasolo FC, Mpabalwani M, Mizuta K, Luo NP, Suzuki H, et al: Prevalence of hepatitis $B$ antigens in human immunodeficiency virus type 1 seropositive and seronegative pregnant women in Zambia. Trans R Soc Trop Med Hyg 1996, 90:235-236.

35. Di Bisceglie AM, Maskew M, Schulze D, Reyneke A, McNamara L, Firnhaber C: HIV-HBV coinfection among South African patients receiving antiretroviral therapy. Antivir Ther 2010, 15(3 Pt B):499-503. 45.

36. Belay $T$, Gizachew $Y$, Afework $K$, Anteneh $A$, Andargachew $M$, Frank $E$, Ulrich S: Seroprevalence of HIV, HBV, HCV and syphilis infections among blood donors at Gondar University Teaching Hospital, Northwest Ethiopia: declining trends over a period of five years. BMC Infect Dis 2010, 10:111.

37. Lukhwareni A, Burnett RJ, Selabe SG, Mzileni MO, Mphahlele MJ: Increased detection of HBV DNA in HBsAg-positive and HBsAg-negative South African HIV/AIDS patients enrolling for highly active antiretroviral therapy at a Tertiary Hospital. J Med Virol 2009, 81:406-412.

38. Lesi OA, Kehinde MO, Oguh DN, Amira CO: Hepatitis B and C virus infection in Nigerian patients with HIV/AIDS. Niger Postgrad Med J 2007, 14(2):129-133.

39. Lodenyo H, Schoub B, Ally R, Kairu S, Segal I: Hepatitis B and C virus infections and liver function in AIDS patients at Chris Hani Baragwanath, Johannesburg. East Afr Med J 2000, 77(1):13-15.

40. Hoffmann CJ, Charalambous S, Martin DJ, Innes C, Churchyard GJ, Chaisson $R E$, et al: Hepatitis $B$ virus infection and response to antiretroviral therapy (ART) in a South African ART program. Clin Infect Dis 2008, 47:1479-1485.

41. Shimelis T, Torben W, Medhin G, Tebeje M, Andualm A, Demessie F, et al: Hepatitis $B$ virus infection among people attending the voluntary counselling and testing centre and anti-retroviral therapy clinic of St Paul's General Specialised Hospital, Addis Ababa, Ethiopia. Sex Transm Infect 2008, 84:37-41.

42. Ampofo W, Nii-Trebi N, Ansah j, Abe K, Naito H, Aidoo S, Nuvor V, Brandful J, Yamamoto N, Ofori-Adjei D, Ishikawa K: Prevalence of Bloodborne Infectious Diseases in blood donors in Ghana. J Clinical Microbiology 2002, 40:3523-3525

43. Okoth F, Mbuthia J, Gatheru Z, Murila F, Kanyingi F, Mugo F, Esamai F, Alavi Z, Otieno J, Kiambati H, Wanjuki N: Seroprevalence of hepatitis B markers in pregnant women in Kenya. East Afr Med J 2006, 83:485-493.

44. Otedo AEHBV: HIV co-infection at Kisumu district hospital, Kenya. East Afr Med J 2004, 81(12):626-630.

45. Ejele OA, Nwauche CA, Erhabor O: The Prevalence of Hepatitis B surface Antigenaemia in HIV positive patients in the Niger Delta Nigeria. Niger $J$ Med 2004, 13(2):175-179.

46. Mustapha S, Jibrin Y: The prevalence of hepatitis B surface antigenaemia in patientys with Human Immunodeficiency virus (HIV) infection in Gombe, Nigeria. Annual African Medical J 2004, 3:10-12. 
47. Kasolo F, Sakala I, Baboo K: Hepatitis B virus infection in human immunodeficiency virus seropositive patients at the University Teaching Hospital, Lusaka, Zambia: Interrelationship. [Abstract no. 963]. 2 nd IAS. Paris, France: Conference on HIV Pathogenesis and Treatment; 2003.

48. Sud A, Singh J, Dhiman RK, Wanchu A, Singh S, Chawia Y: Hepatitis B virus co-infection in HIV infected patients. Trop Gastroenterol 2001, 22(2):90-92.

49. Rahlenbeck S, Yohannes G, Molla K, Reifen R, Assefa A: Infection with HIV, Syphilis and hepatitis B in Ethiopia: A survey in blood donors. Int J STDS AIDS 1997, 8:261-264.

50. Mutuma GZ, Mbuchi MW, Zeyhle E, Fasana R, Okoth FA, Kabanga MJ, Kuria J, Shiramba LT, Njenga KM, Kaiguri PM, Osidiana V: Prevalence of Hepatitis $B$ Virus (HBV) surface antigen and HBV-associated hepatocellular carcinoma in Kenyans of various ages. Afr J Health Sci 2011, 18:53-61.

51. Wester CW, Bussmann H, Moyo S, Avalos A, Gaolathe T, Ndwapi N, et al: Serological evidence of HIV-associated infection among HIV-1-infected adults in Botswana. Clin Infect Dis 2006, 43:1612-1615.

52. Taiwo Modupe B, Samuel E, Emmanuel Folorunso O: HIV, Hepatitis B and C viruses' coinfection among patients in a Nigerian tertiary hospital. Pan African Medical J 2012, 12:100.

53. Firnhaber C, Reyneke A, Schulze D, Malope B, Maskew M, MacPhail P, et al: The prevalence of hepatitis $B$ co-infection in a South African urban government HIV clinic. S Afr Med J 2008, 98:541-544.

\section{doi:10.1186/1756-0500-6-363}

Cite this article as: Muriuki et al:: Prevalence of hepatitis B and C viral co-infections among HIV-1 infected individuals in Nairobi, Kenya. BMC Research Notes 2013 6:363.

\section{Submit your next manuscript to BioMed Central and take full advantage of:}

- Convenient online submission

- Thorough peer review

- No space constraints or color figure charges

- Immediate publication on acceptance

- Inclusion in PubMed, CAS, Scopus and Google Scholar

- Research which is freely available for redistribution 